5 Czerwinski AW, Czerwinski AB, Whitsett TL, Clark $M L$. Effects of a single, large, intravenous injection of dexamethasone. Clin Pharmacol Ther 1972; 13: $638-42$.

\section{Lumbar epidural anesthesia and celiac plexus blockade for cholecystectomy in two patients with severe chronic obstructive pulmonary disease}

\section{To the Editor:}

Open cholecystectomy (OC) usually necessitates general anesthesia and endotracheal intubation. General anesthesia + epidural anesthesia (EA), thoracic EA, EA + intrapleural anesthesia, EA + iv anesthesia, and EA + local anesthesia have been used for upper abdominal surgery (UAS) in patients with pulmonary disease previously. ${ }^{1-3}$ Although celiac plexus blockade $(\mathrm{CPB})$ can be recommended as an adjunct to EA for UAS, it is not common because of technical difficulties and risks. We report the effects of combined $\mathrm{CPB}$ and EA on metabolic and endocrine responses to surgery, respiratory function and pain intensity in two patients with chronic obstructive pulmonary disease (COPD) for OC.

Case 1: A woman (44 yr old) with chronic cholelithiasis had bronchiectasis (wheezing, sibilant rhonchi and clubbing) for ten years. $\left(\mathrm{FEV}_{1} / \mathrm{FVC}\right.$ : $60 \%$ and $\mathrm{pH}: 7.43, \mathrm{PaCO}_{2}: 29 \mathrm{mmHg}, \mathrm{PaO}_{2}: 85$ $\mathrm{mmHg}, \mathrm{BE}:-3 \mathrm{mmol} \cdot \mathrm{L}^{-1}, \mathrm{SaO}_{2}: 96 \%$.)

Case 2: A woman (65 yr old) had COPD (expiratory wheezing and rhonchi) and hypertension. $\left(\mathrm{FEV}_{1} /\right.$ FVC: 58\%, pH: 7.46, $\mathrm{PaCO}_{2}: 44 \mathrm{mmHg}, \mathrm{PaO}_{2}: 70$ $\mathrm{mmHg}$, BE: $\left.6.9 \mathrm{mmol} \cdot \mathrm{L}^{-1}, \mathrm{SaO}_{2}: 95 \%\right)$. Both patients were admitted for OC. Other laboratory tests were normal.

Lumbar EA and CPB were planned in order to prevent deep visceral pain during OC. Premedication and bronchodilator medication were given. With standard monitors in place, an epidural catheter was placed at the Ll-2 level. A test dose ( $3 \mathrm{~mL} 1.5 \%$ lidocaine with 1:200,000 epinephrine) was given and $6 \mathrm{~mL}$ bupivacaine $0.25 \%$ given to provide analgesia during CPB by a posterior approach with a $12-\mathrm{cm} 22$ gauge needle. After a test dose, $30 \mathrm{~mL} 0.25 \%$ bupivacaine were injected to the celiac plexus bilaterally. After $15 \mathrm{~min}$, $16 \mathrm{~mL} 0.25 \%$ bupivacaine were given epidurally and sensory blockade reached the T4 dermatome level in both patients.

During the procedure, mild hypotension was corrected with ephedrine 5 to $10 \mathrm{mg} i v$. Shivering was treated with meperidine 12.5 to $20 \mathrm{mg}$ iv and midazo- lam $2 \mathrm{mg} i v$ was administered for sedation. The patients felt moderate pain [visual analogue scale (VAS) 4-5] only during subhepatic retraction, relieved with fentanyl $50 \mu \mathrm{g} i v$. Forty-five minutes into surgery, blood glucose and cortisol levels were normal or slightly elevated. At the end of surgery, bupivacaine $0.25 \% 8 \mathrm{~mL}$ was given epidurally for postoperative analgesia. Eight hours after surgery, pain (VAS 5-7) was relieved with $0.25 \%$ bupivacaine $8 \mathrm{~mL}$ epidurally. Intraoperative and postoperative arterial blood gas analyses were normal. The epidural catheters were removed on the morning after surgery. Postoperatively, glucose and cortisol levels were in the normal range. No complications of $\mathrm{CPB}$ were observed. The patients were discharged on the fourth and fifth day after surgery.

The celiac and splanchnic nerves are responsible for producing endocrine-metabolic responses to gastric surgery even under epidural blockade. ${ }^{4}$ Even when sensory blockade reaches the T4 dermatome sensory blockade to the viscera can be inadequate. ${ }^{5}$ It has been suggested that celiac plexus or superior hypogastric blockade should be performed in UAS. ${ }^{5}$

In conclusion, cholecystectomy can be performed under EA with $\mathrm{CPB}$, almost inhibiting the stress responses to surgery, in patients with severe COPD. Cases should be selected carefully and CPB should be practiced by a skilled anesthesiologist. Alternatively, an intraoperative abdominal approach for $\mathrm{CPB}$ can be considered in order to prevent complications. Further studies are needed to compare EA and EA plus CPB for cholecystectomy in patients with severe COPD.

\section{Elif Bengi Sener MD}

Serhat Kocamanoglu MD

Emre Ustun MD

Zafer Malazgirt MD

Ayla Tur MD

Samsun, Turkey

Presented at Euroanesthesia 2003 in Glasgow, Scotland.

\section{References}

1 Konichezky S, Szmuk P, Ezri T, Soroker D, Ben-Abaron $U$, Pfefferman R. Combined intrapleural and low epidural anesthesia for upper abdominal surgery (Hebrew). Harefuah 1995; 128: 269-71.

2 Shipulin AA, Vasil'ev IuS, Karasev GB, Murav'ev GK, Martynov AN. Combined intravenous and epidural anesthesia in laparoscopic surgery (Russian). Anesteziol Reanimatol 1999; 6: 65-6.

3 Kouraklis G, Glinavou A, Raftopoulos L, Alevisou V, Lagos $G$, Karatzas $G$. Epidural analgesia attenuates the 
systemic stress response to upper abdominal surgery: a randomized trial. Int Surg 2000; 85: 353-7.

4 Tsuji H, Shirasaka C, Asoh T, Takeuchi $\Upsilon$. Influences of splanchnic nerve blockade on endocrine-metabolic responses to upper abdominal surgery. Br J Surg 1983; 70: 437-9.

5 Campbell IT. Anesthesia for abdominal surgery. In: Nunn JF, Utting JE, Brown BR Jr (Eds). General Anesthesia, fifth edition. London: Buttersworth \& Co Ltd; 1989: 823-33.

\section{Transcutaneous electrical nerve stimu- lation prevents visceral pain in mice}

To the Editor:

We assessed transcutaneous electrical nerve stimulation (TENS) antinociceptive activity in visceral pain in an experimental murine model.

Sixty-four mice were divided into eight groups. Group I, received perezone, ip while Group II received only the vehicle. The $5 \mathrm{mg} \cdot \mathrm{kg}^{-1}$ dose was chosen based on the results obtained in a previous dose-response study to perezone. The number of abdominal constrictive responses (ACR) was registered immediately after its administration. TENS electrodes were placed on Group III without stimulation during $30 \mathrm{~min}$; afterwards, the mice received perezone ip. Groups IV to VIII underwent TENS (by means of two electrodes in the mouse's abdominal wall at different frequencies $(10,20,40,80$, and 160 $\mathrm{Hz}$ ) during $30 \mathrm{~min}$. Immediately after the stimulation period, these last groups received perezone $i p$ and the number of ACR was recorded.

A stimulator [Acupoint 2000, Instituto Politécnico Nacional (IPN) Mexico City, Mexico] was used for the generation of the electric impulses of TENS, with fixed parameters for all groups (except for the stimulation frequency); the pulse amplitude was $150 \mathrm{~J} \cdot \mathrm{sec}^{-1}$, the relaxation pattern $1.8 \mathrm{sec}$, and the contraction pattern four seconds. Outcomes were analyzed with the Kruskal Wallis test and a $P \leq 0.05$ was considered statistically significant.

Perezone induced ACR accompanied by behavioural and autonomic responses (defecation, urination and tachycardia). The average of ACR during the observation in Group I TENS was 6.75 contractions, while it was zero for Group II.

For mice from Group III that only underwent electrode placement without stimulation before receiving perezone, ACR averaged seven contractions. The mice from Groups IV, V, VI and VII that underwent TENS

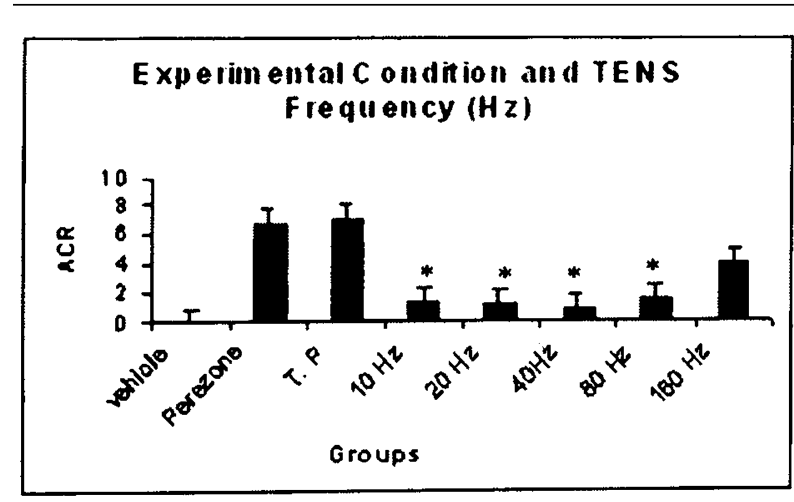

FIGURE The influence of transcutaneous electrical stimulation on the abdominal constrictive response in eight groups of eight mice.

30 min with frequencies of $10,20,40$, and $80 \mathrm{~Hz}$ before the administration of perezone presented significant inhibition of ACR $(P<0.05)$ of $83,87,92$ and $74 \%$, respectively. Finally, in Group VIII the inhibition of the nociceptive effect was of $20 \%(P>0.05$; Figure).

We conclude that a decrease in ACR induced by perezone can be observed when TENS is applied at low frequencies. Applied prior to nociception, TENS appears to be useful as a non-pharmacological resource for visceral pain management.

Uriah Guevara López MD PhD

Alfonso E. Campos Sepúlveda MD PhD

Javier Gómez Parra MD

Antonio Tamayo Valenzuela MD

Ramón De Lille Fuentes MD

María E. Martínez Enríquez PhD

Colonia Tlalpan, Mexico

\section{References}

1 Cervero F. Sensory innervation of the viscera: peripheral basis of visceral pain. Physiol rev 1994; 74: 95-138.

2 Borjesson $M$, Pilhall M, Eliasson T, Norssell $H$, Mannheimer $C$, Rolny P. Esophageal visceral pain sensitivity: effect of TENS and correlation with manometric findings. Dig Dis Sci 1998; 43: 1621-8.

3 Han JS, Chen XH, Sun SL, et al. Effect of low- and high-frequency TENS on Met-enkephalin-Arg-Phe and dynorphin A immunoreactivity in human lumbar CSF. Pain 1991; 47: 295-8.

4 Garcia X, Alcantara-Sarabia G, Cartas-Heredia L, Gijon E. Actions of perezone on rat smooth muscle. Gen Pharmacol 1995; 26: 1741-5. 